\title{
THE COLOR BLACK AND SITUATIONAL CONTEXT: FACTORS INFLUENCING PERCEPTION OF AN INDIVIDUAL'S AGGRESSIVENESS AND RESPECTABILITY
}

\author{
Pavla LINHARTOVÁ, Adam TAPAL, Luboš BRABENEC, Radomir MACECEK, \\ Jan Jiří BUCHTA, Jakub PROCHÁZKA ${ }^{1}$, Stanislav JEŽEK, Martin VACULÍK \\ ${ }^{1}$ Masaryk University, Faculty of Social Studies, Department of Psychology \\ Jostova 10, 60200 Brno, Czech Republic \\ E-mail: jak.prochazka@mail.muni.cz
}

\begin{abstract}
The article is focused on the influence of black colored clothing and situational context on impression formation. We examinated whether individuals are evaluated as more aggressive (1) when they are wearing black clothing, (2) in an aggressive situational context. Furthermore, we examinated whether individuals are evalued as more respectable (1) when they are wearing black clothing (2) in more respectable situational context. The sample consisted of 475 high school students who assessed individuals displayed in computer-modified photographs wearing randomly chosen colors in randomly chosen contexts. We show that men unlike women are evaluated as more aggressive when wearing the color black. Black colored clothing does not have influence on the assessment of one's respectability. Both men and women are evaluated as more aggressive in aggressive situational contexts and also as more respectable in more respectable situational contexts regardless of the color of their clothing.
\end{abstract}

Key words: aggressiveness, respectability, perception, black color, context

The first impression of an individual can be greatly influenced by the clothing one is wearing at the time of the first encounter. Both the style and color of the clothing are important when forming the first impression, and the color is more important than one's facial expression (Radeloff, 1990). Black color has a very specific influence, as it is in many cultures connected with death (Adams, Osgood, 1973) and amorality (Sherman, Clore, 2009). Kaya and Epps (2004) examined what kind of emotions are induced by various colors. The color black induced mostly (in 78.6\% of cases) negative emotions, most frequently sadness, depression and fear. When watching two different versions of a soccer match, a soccer team was deemed as more aggres- sive when their soccer jerseys were black as opposed to a lighter color (Frank, Gilovich, 1988). In an assessment of the guilt and aggressiveness of a suspect in a photograph, the suspect was seen as guilty and more aggressive more frequently when his/her clothing was black (Vrij, 1997). Policemen wearing black uniforms where evaluated as less friendly and more aggressive in comparison with those wearing blue or white khaki uniforms (Johnson, 2005). According to Frank and Gilovich (1988), individuals wearing black are in general considered by others to be more aggressive, or even as behaving more aggressively.

Based on the previous research, we believe that the color black should influence

DOI: $10.21909 / \mathrm{sp} .2013 .04 .646$ 
the perceived aggressiveness examined in aggressive contexts - i.e., in circumstances when an aggressive behavior of the actors was expected (a suspect, a sport event resembling a fight, a person in a uniform expected to carry a gun). The situational context itself also influences one's reasonining. It has an impact on evaluation of colors (e.g., Maier et al., 2009), as well as people (e.g., Wittenbrink et al., 2001). One can expect that black clothing in combination with aggressive situational context increases the perceived aggressiveness of a person. Can one expect the influence of the color black on perceived aggressiveness only in aggressive situational contexts? How is it manifested in other situational contexts?

According to Damhorst and Reed (1986), managers evaluate job applicants wearing black clothing as possesing more integrity and greater moral reputaion. Individuals wearing black clothing also have a greater influence on a group (Vrij, Pannell, Ost, 2005). In many cultures, the color black is a color expected in various cultural situations that are not necessarily connected with aggressiveness, but rather have a great social importance, e.g., at a funeral, business meeting, awarding national badge of honour or participation in job interviews. Thus, we hypothesize that the color of clothing will induce respectability.

One's perception as aggressive and respectable at the same time is not exclusive. We believe that the black color of clothing can influence simultaneously the perception of aggressivenss and respectability, and that the complementary situational context can strengthen the influence of those variables. For instance, black-wearing policeman can be perceived more positively than policeman wearing a different color (Nickels, 2008).
We decided to examine the influence of the color of black clothing on one's perception as being aggressive in other than an aggressive context. Moreover, we examined the influence of black clothing on one's perpcetion as being respectable. The following contexts were used: aggressive, respectable and unspecified as a control. Impact of the black color of clothing on one's first impression of an individual and how this impact is strengthened or diminished by situtional context was the goal of our study. The following hypotheses were established:

$\mathrm{H} 1$ : Individuals in black clothing are perceived as more aggressive in comparison with individuals in lighter clothing even in other than aggressive situational context.

$\mathrm{H} 2$ : The influence of the black color of clothing on one's perceived aggressiveness is greater in an aggressive situational context than in a non-aggressive situational context.

H3: Individuals in black clothing are perceived as more respectable than those in lighter colors.

H4: Influence of the black color of clothing on perceived respectability of a person is greater in a more respectable context than in other situational contexts.

\section{METHOD}

The participants were asked to judge men and women in photographs wearing either black or light grey clothing. The light grey color was chosen as a neutral representant among light colors. The color grey, similar to the color black, is common for social occasions and it is not connected with eccentricity. Provided that it is a color on the border between black and grey, it can be seen as a color lighter than black. Each photograph was 
presented in aggressive, respectable and unspecified contexts. In order to assess the aggressiveness or respectability of the person presented in the photograph, participants used a set of adjectives. Using photographs instead of real-world actors helped keep many potential intervening factors constant (such as behavior or facial expression of actors).

\section{Participants}

The participants were students from four different Czech high schools $(\mathrm{N}=475)$. The research was conducted as a part of a class course and from the results students learned new information about perception and evaluation of others. All students from selected classrooms were included in the experiment. The classrooms were chosen randomly. All participants volunteered in the research. The sample was homogenous age-wise (15-20 yrs; $\mathrm{M}=16.94$; $\mathrm{SD}=1.07)$ and girls outnumbered boys (195 boys, 276 girls).

\section{Materials}

Two photographs, one of a man and one of a woman, were used. Photographs of the actors of different genders were used because gender of the evaluated person is a variable that influences the perception of aggressiveness (Turner, 1992). Both actors had a neutral facial expression in the photographs, no secondary attributes connected with respectability or aggressiveness (moustache, glasses, eccentric haircut) were presented. Each wore a long-sleeve shirt and solid color pants; the background was white. The color of their clothing was modified using computer software so the actor wore either black or light grey clothing. Each pho- tograph was presented in one of the three situational contexts: a) an aggressive context (the following sentence was presented in the photograph: This person is suspected of a violent offence), b) respectable context (the following sentence was presented in the photograph: This person is a participant in a job selection process for the position of state prosecutor), c) unspecified context (no text was presented in the photograph). Factorial combinations of clothing color and situational contexts resulted in six versions of each photograph (each version and its frequency of usage are listed in Table 1).

The respectability and aggressiveness of the persons presented in photographs was judged by participants using a questionnaire listing various adjectives. We used 12 adjectives, from which 3 were related to aggressiveness (aggressive, rude, belligerent), 3 were related to respectability (trustworthy, respectable, responsible) and 6 of them did not relate to any of the presented contexts (sensitive, interesting, discreet, quiet, friendly, nervous). Those last unrelated adjectives were used so the participants would not discover the purpose of the study.

Pariticipants had to assess the person in the photograph in relation to each of the adjective on a 5-point scale (1-5). If the participant believed that the adjective does not correspond to the person presented in the photograph at all, the respective scale could be ignored. Furthermore, s/he could write his/ her own impression, using whatever adjective not listed amongst the ones provided as a part of the questionnaire.

\section{Procedure}

The data was gathered from individual classrooms during a class course. At the 
beginning of the class, the researcher greeted the students and asked them for participation in a psychological experiment in which they will judge photographs of people. Consequently, s/he informed them about the voluntary participation and anonyminity of the research and explained the instructions. Furthermore, s/he asked them to judge the photographs independently from other classmates. Afterwards, each participant was given two questionnaires and two randomly chosen photographs (one female and one male). The photographs were presented face down and the participant was instructed to judge them one by one.

The clothing color in the photographs and the situational contexts were presented randomly. Individuals in the photographs wore different color clothing. Similarly, the situational context was either the same or different. After judging the photographs, the researcher collected both the photographs and questionnaires. At the end, the researchers debriefed the participants and promised to share the results after its analysis.

The perceived aggressiveness of the person in the photograph was judged using various adjectives related to aggression. Each of the three presented adjectives was judged on a five-point scale ( 0 in case the participant did not find the adjective to be related). The sum of the scores from all three adjectives from an individual subject represented the value of the variable "aggressiveness". The values ranged from 0-15. Using the same principle, the variable "respectability" was attained.

\section{RESULTS}

Table 1 shows the statistics for the descriptive terms related to aggressiveness and re- spectability. In order to compute the influence of clothing color and context on perceived aggressiveness, a Factorial Analysis of Variance 2 (clothing color) x 3 (situational context) $\mathrm{x} 2$ (gender of the subject) was used. We carried out separate analyses for photographs of men and women in order to keep the potential influence of the subject's gender constant. Subject's gender was then transformed into an independent variable in order to control for its influence. The results of those four analyses are summarized in Table 2 .

H1: Individuals wearing black clothing are perceived as more aggressive in comparison with individuals wearing lighter colors even in other than aggressive situational contexts.

The influence of clothing color on the perceived aggressivenss of a person in a photograph is significant only in case when men are displayed in the photograph $(\mathrm{F}(1,452)=$ $16.76, \mathrm{p}<.01$, partial $\left.\eta^{2}=.04\right)$. Clothing color does not have any significant influence on the perceived aggressiveness of women $\left(\mathrm{F}(1,452)=2.45, \mathrm{p}=.12\right.$, partial $\left.\eta^{2}=.01\right)$. The hypothesis was, thus, confirmed only for men who are, regardless of the context, perceived as more aggressive when wearing black clothing.

The controlled-for variable, gender of the participants, has a significant impact on perceived aggressiveness only for women $\left(\mathrm{F}(1,452)=9.82, \mathrm{p}<.01\right.$, partial $\left.\eta^{2}=.02\right) . \mathrm{A}$ woman presented in a photograph was perceived as more aggressive by men than by women. None of the interactions of gender and other predictors were significant (see Table 2).

$\mathrm{H} 2$ : The influence of black clothing on perceived aggressivenss is greater in aggressive than in non-aggressive situational contexts. 
Table 1. Descriptive statistics for individual groups divided by gender, context and clothing color

\begin{tabular}{|c|c|c|c|c|c|c|c|c|}
\hline \multirow{2}{*}{$\begin{array}{l}\text { Photo } \\
\text { Gender }\end{array}$} & \multirow{2}{*}{$\begin{array}{c}\text { Respondent } \\
\text { Gender }\end{array}$} & \multirow{2}{*}{$\begin{array}{l}\text { Dress } \\
\text { Color }\end{array}$} & \multirow{2}{*}{ Context } & \multirow{2}{*}{$\mathrm{N}$} & \multicolumn{2}{|c|}{ Aggressiveness } & \multicolumn{2}{|c|}{ Respectability } \\
\hline & & & & & $\mathrm{M}$ & SD & $\mathrm{M}$ & $\mathrm{SD}$ \\
\hline \multirow[t]{12}{*}{ Male } & \multirow[t]{6}{*}{ Male } & \multirow[t]{3}{*}{ Black } & Aggressive & 35 & 7.40 & 4.06 & 6.26 & 3.42 \\
\hline & & & No Context & 33 & 4.39 & 3.82 & 7.18 & 4.77 \\
\hline & & & Respectable & 31 & 4.65 & 3.04 & 8.16 & 3.41 \\
\hline & & \multirow[t]{3}{*}{ Grey } & Aggressive & 35 & 3.89 & 3.41 & 6.00 & 3.75 \\
\hline & & & No Context & 25 & 3.32 & 2.91 & 6.96 & 4.82 \\
\hline & & & Respectable & 33 & 3.82 & 3.77 & 7.79 & 4.17 \\
\hline & \multirow[t]{6}{*}{ Female } & \multirow[t]{3}{*}{ Black } & Aggressive & 43 & 5.72 & 4.27 & 4.77 & 4.16 \\
\hline & & & No Context & 42 & 4.50 & 3.59 & 6.64 & 3.96 \\
\hline & & & Respectable & 50 & 3.90 & 4.03 & 7.98 & 3.73 \\
\hline & & \multirow[t]{3}{*}{ Grey } & Aggressive & 47 & 4.87 & 4.57 & 4.81 & 3.55 \\
\hline & & & No Context & 46 & 2.54 & 2.70 & 5.96 & 3.95 \\
\hline & & & Respectable & 44 & 3.39 & 3.85 & 6.55 & 3.89 \\
\hline \multirow[t]{12}{*}{ Female } & \multirow[t]{6}{*}{ Male } & \multirow[t]{3}{*}{ Black } & Aggressive & 36 & 5.36 & 3.62 & 5.97 & 3.91 \\
\hline & & & No Context & 28 & 4.50 & 3.69 & 7.57 & 3.30 \\
\hline & & & Respectable & 42 & 4.29 & 3.40 & 8.88 & 3.31 \\
\hline & & \multirow[t]{3}{*}{ Grey } & Aggressive & 31 & 4.32 & 4.16 & 6.68 & 3.83 \\
\hline & & & No Context & 31 & 3.84 & 3.03 & 6.90 & 4.09 \\
\hline & & & Respectable & 24 & 3.63 & 3.32 & 9.50 & 3.22 \\
\hline & \multirow[t]{6}{*}{ Female } & \multirow[t]{3}{*}{ Black } & Aggressive & 46 & 3.93 & 4.12 & 7.59 & 3.72 \\
\hline & & & No Context & 48 & 3.04 & 3.08 & 6.94 & 4.32 \\
\hline & & & Respectable & 42 & 3.24 & 3.67 & 7.24 & 4.18 \\
\hline & & \multirow[t]{3}{*}{ Grey } & Aggressive & 48 & 4.33 & 3.87 & 5.08 & 3.97 \\
\hline & & & No Context & 42 & 2.67 & 3.13 & 7.33 & 3.89 \\
\hline & & & Respectable & 46 & 2.43 & 2.83 & 7.78 & 3.71 \\
\hline
\end{tabular}

Table 2. Factorial Analysis of Variance for dependent variables aggressiveness and respectability

\begin{tabular}{|l|c|c|c|c|c|c|c|c|c|}
\hline \multirow{2}{*}{} & \multirow{2}{*}{} & \multicolumn{4}{|c|}{ Aggressiveness } & \multicolumn{4}{c|}{ Respectability } \\
\cline { 2 - 11 } & df & Photo - male & Photo - female & \multicolumn{2}{c|}{ Photo - male } & \multicolumn{2}{c|}{ Photo - female } \\
\cline { 2 - 10 } & & $\begin{array}{c}\text { partial } \\
\eta^{2}\end{array}$ & $\mathrm{~F}$ & $\begin{array}{c}\text { partial } \\
\eta^{2}\end{array}$ & $\mathrm{~F}$ & $\begin{array}{c}\text { partia } \\
\eta^{2}\end{array}$ & $\mathrm{~F}$ & $\begin{array}{c}\text { partial } \\
\eta^{2}\end{array}$ \\
\hline Error & 452 & & & & & & & & \\
\hline Respondent Gender & 1 & 1.42 & .00 & $9.82^{* *}$ & .02 & $6.34^{*}$ & .01 & 2.61 & .01 \\
\hline Dress Color & 1 & $16.76^{* *}$ & .04 & 2.45 & .01 & 1.71 & .00 & 0.17 & .00 \\
\hline Photo Context & 2 & $10.01^{* *}$ & .04 & $4.42^{*}$ & .02 & $11.65^{* *}$ & .05 & $10.41^{* *}$ & .04 \\
\hline Gender*Color & 1 & 0.97 & .00 & 0.62 & .00 & 0.30 & .00 & 1.02 & .00 \\
\hline Gender*Context & 2 & 0.05 & .00 & 0.29 & .00 & 0.30 & .00 & 2.22 & .01 \\
\hline Color*Context & 2 & 1.57 & .01 & 0.13 & .00 & 0.39 & .00 & 1.40 & .01 \\
\hline Gender*Color*Context & 2 & 2.16 & .01 & 0.51 & .00 & 0.29 & .00 & $3.13^{*}$ & .01 \\
\hline
\end{tabular}

Note: $\mathrm{N}=464 ; * \mathrm{p} \leq .05 ; * * \mathrm{p} \leq .01$ 
The perceived aggressiveness of men and women is significantly influenced by situational contexts (Male: $\mathrm{F}(1,452)=10.01, \mathrm{p}<$ .01 , partial $\eta^{2}=.04$; Female: $F(1,452)=4.42$, $\mathrm{p}=.01$, partial $\eta^{2}=.02$ ). Using post-hoc tests, significant differences between aggressive situational contexts and other contexts were found ${ }^{1}$. The difference between situational and unspecified contexts was insignificant. Individuals wearing black are perceived in aggressive contexts as being more aggressive than in other contexts (see Figures 1 and 2, Figures 3 and 4), because the influence of context and clothing color add up together. However, the interaction is insignificant. Situational context thus impacts perceived aggressiveness regardless of clothing color.

$\mathrm{H} 3$ : Individuals in black clothing are perceived as more respectable in comparison with those in lighter clothing color.

The influence of clothing color on perceived respectability was not found to be significant either for men or women (Male: $\mathrm{F}(1,452)=1.70, \mathrm{p}=.19$, partial $\eta^{2}=.00 ; \mathrm{Fe}-$ male: $F(1,452)=0.17, p=.68$, partial $\eta^{2}=.00$, see Figures 5 and 6 ). One cannot say that individuals wearing black are perceived as being more respectable in comparison with those wearing light colors. The participant's gender had a significant influence on the perceived respectability of men $(F(1,452)=$ $6.34, p=.01$, partial $\eta^{2}=.01$ ). Male actors presented in photographs were perceived as more respectable by men compared to women. The interaction of gender and clothing color, and gender and situational context is insignificant (see Table 2).

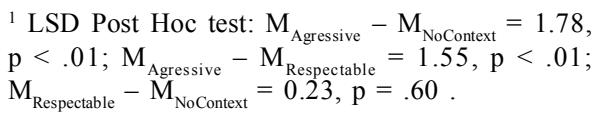

H4: The effect of black clothing on the perceived respectability of an individual is greater in respectable situational contexts compared to other contexts.

Context has a significant effect on the perceived respectability of both men and women (Men: $\mathrm{F}(1,452)=11.65, \mathrm{p}<.01$, partial $\eta^{2}=$ .05 ; Women: $\mathrm{F}(1,452)=10.41, \mathrm{p}<.01$, partial $\left.\eta^{2}=.04\right)$. Post-hoc tests demonstrated that in terms of the evaluation of women, significant differences between respectable and other contexts were found, whereas between aggressive and unspecified contexts no significant difference was observed. ${ }^{2}$ As shown in Figures 7 and 8, women are perceived as more respectable in respectable contexts than in other contexts. In regards to the evaluation of the respectability of men, post-hoc tests showed a significant difference amongst all three observed contexts. ${ }^{3}$ Men are perceived as most respectable in respectable contexts, less respectable in unspecified contexts and least respectable in aggressive contexts. The effect of interaction between clothing color and situational contexts on perceived respectability of both men and women is insignificant. Both men and women wearing black clothing color are seen as more respectable in respectable situational contexts than in other situational context. This, however, is not due to clothing color.

An interesting case when the effect of interaction of clothing color and situational context on perceived respectability is observed, is when a woman wearing black clothing is judged in aggressive context (see sig-

\footnotetext{
${ }^{2}$ LSD Post Hoc test: $\mathrm{M}_{\text {Agressive }}-\mathrm{M}_{\text {NoContext }}=-0.86$, $\mathrm{p}=.05 ; \mathrm{M}_{\text {Agressive }}-\mathrm{M}_{\text {Respectable }}^{\text {Agressive }}=-1.90, \mathrm{p}<.01$; $\mathrm{M}_{\text {Respectable }}-\mathrm{M}_{\text {NoContext }}=1.04, \mathrm{p}=.02$.

${ }^{3}$ LSD Post Hoc test: $\mathrm{M}_{\text {Agressive }}-\mathrm{M}_{\text {NoContext }}=-1.23$, $\mathrm{p}<.01 ; \mathrm{M}_{\text {Agressive }}-\mathrm{M}_{\text {Respectable }}=-2.20, \mathrm{p}<.01 ;$ $\mathrm{M}_{\text {Respectable }}-\mathrm{M}_{\text {NoContext }}=0.97, \mathrm{p}=.03$.
} 
nificant interaction of clothing color, context and gender in Table 2). In this particular situation, the woman is perceived by female subjects as more respectable compared to a woman wearing light color clothing (see Fig- ure 8). This difference in perceived respectability of women is not manifested in other situational contexts or when the women's respectability is judged by men (see Figure 7).

\section{Photo - gender: male \\ Respondent - gender: male}

$$
\text { black grey }
$$

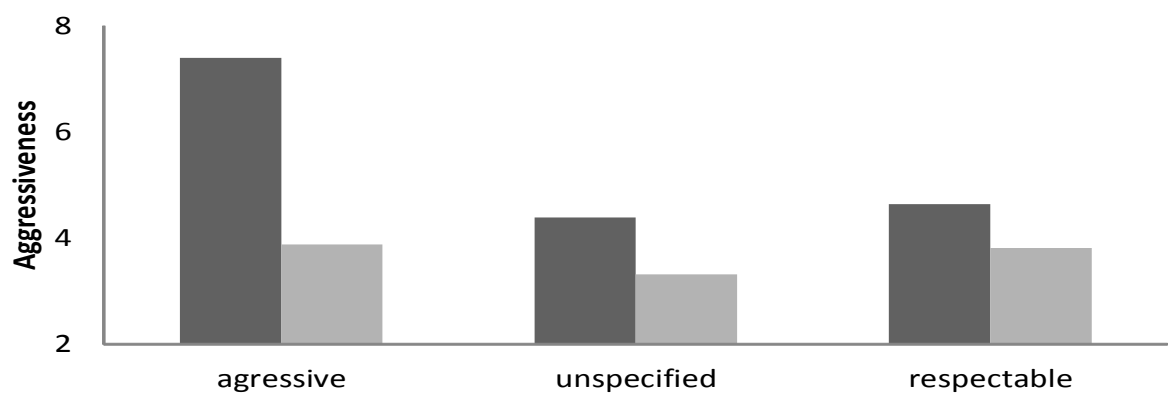

Figure 1. Perceived aggressiveness of male actors as seen by men divided by context and clothing color

\section{Photo - gender: male Respondent - gender: female}

black grey

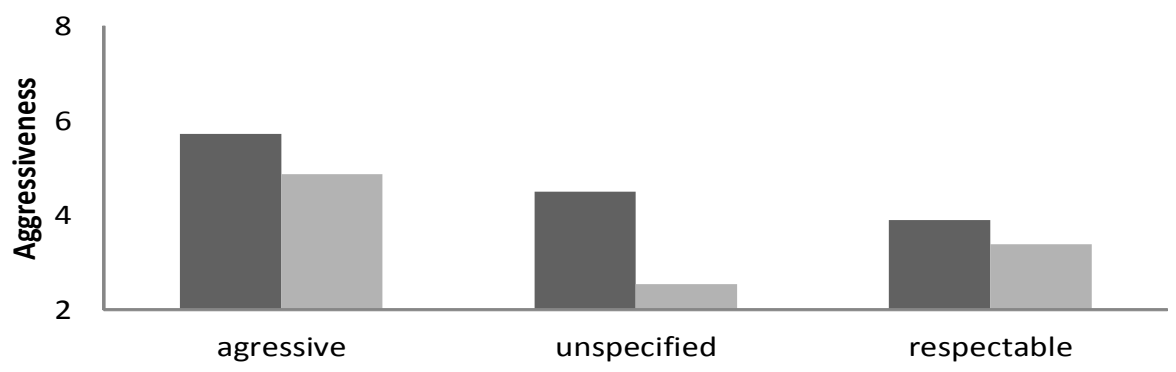

Figure 2. Perceived aggressiveness of male actors as seen by women divided by context and clothing color 


\section{Photo - gender: female Respondent - gender: male

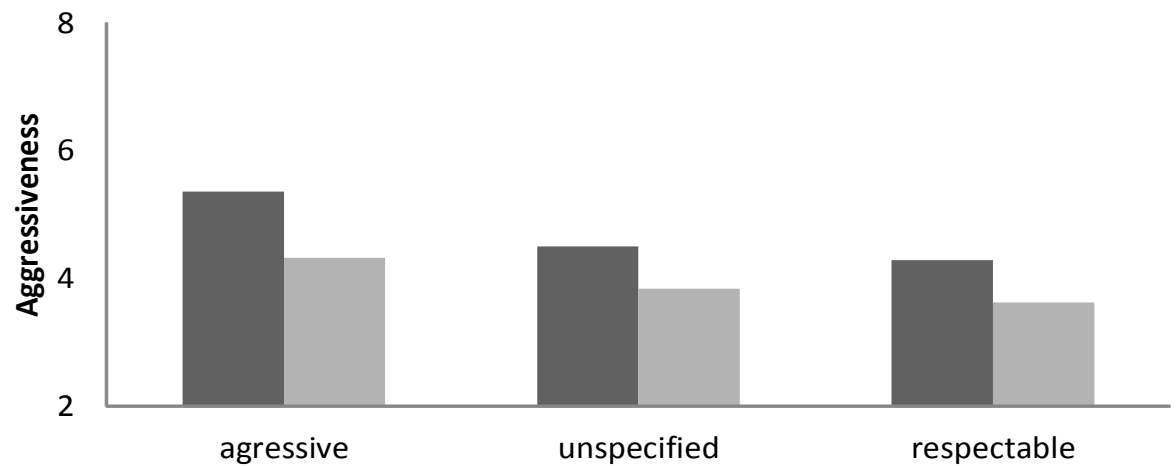

Figure 3. Perceived aggressiveness of female actors as seen by women divided by context and clothing color

Photo - gender: female Respondent - gender: female

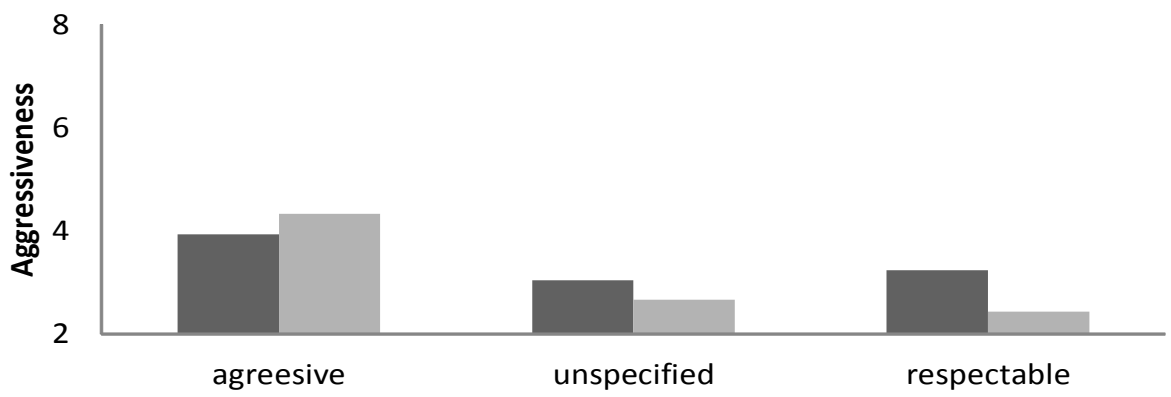

Figure 4. Perceived aggressiveness of female actors as seen by women divided by context and clothing color 
Photo - gender: male

\section{Respondent - gender: male}

- black grey

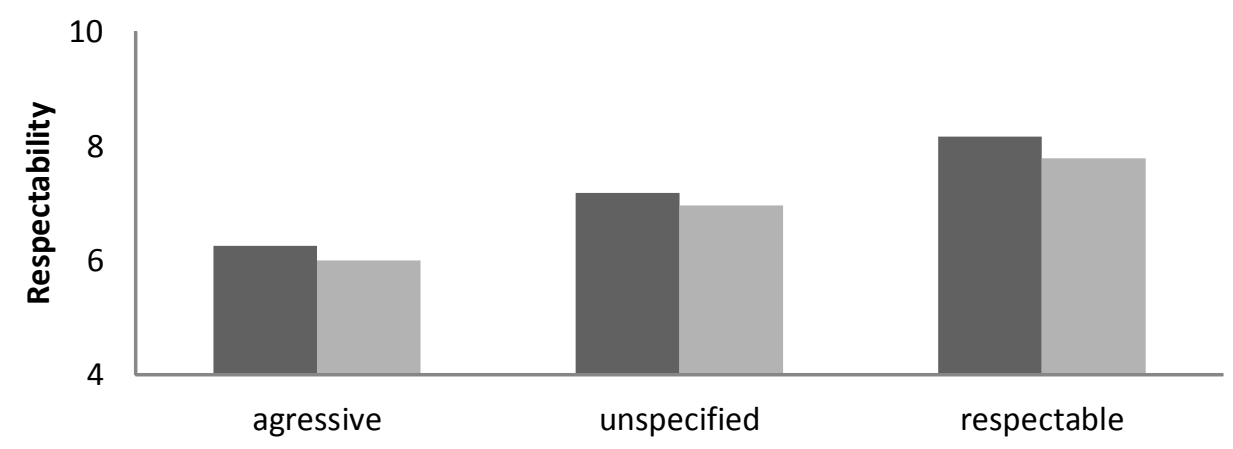

Figure 5. Perceived respectability of male actors as seen by men divided by context and clothing color

\section{Photo - gender: male \\ Respondent - gender: female}

- black grey

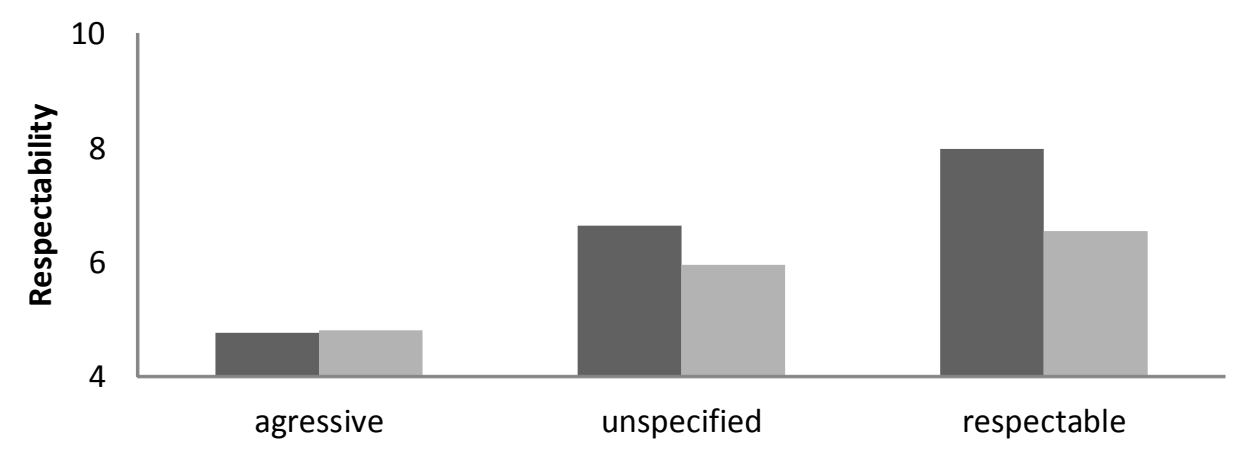

Figure 6. Perceived respectability of male actors as seen by women divided by context and clothing color 
Photo - gender: female

Respondent - gender: male

black grey

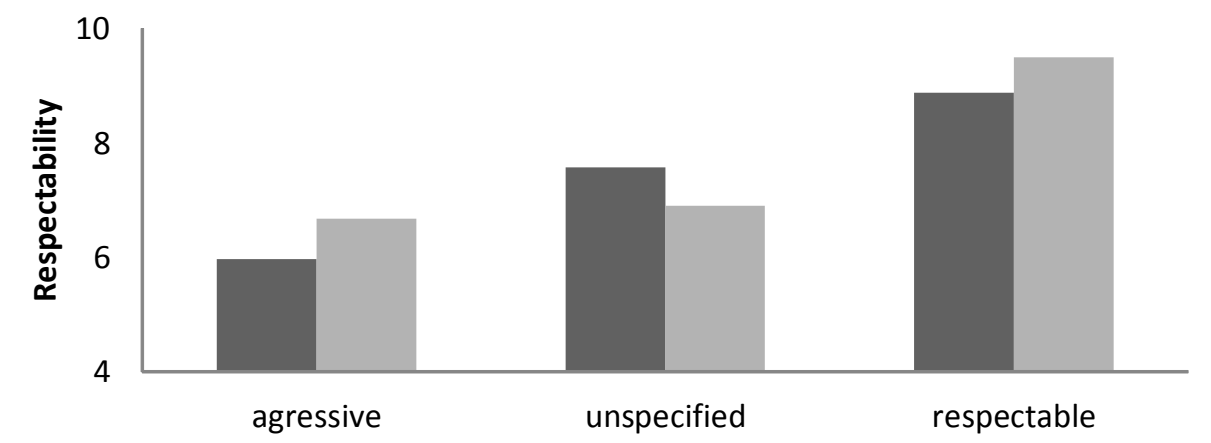

Figure 7. Perceived respectability of female actors as seen by men divided by context and clothing color

\section{Photo - gender: female Respondent - gender: female}

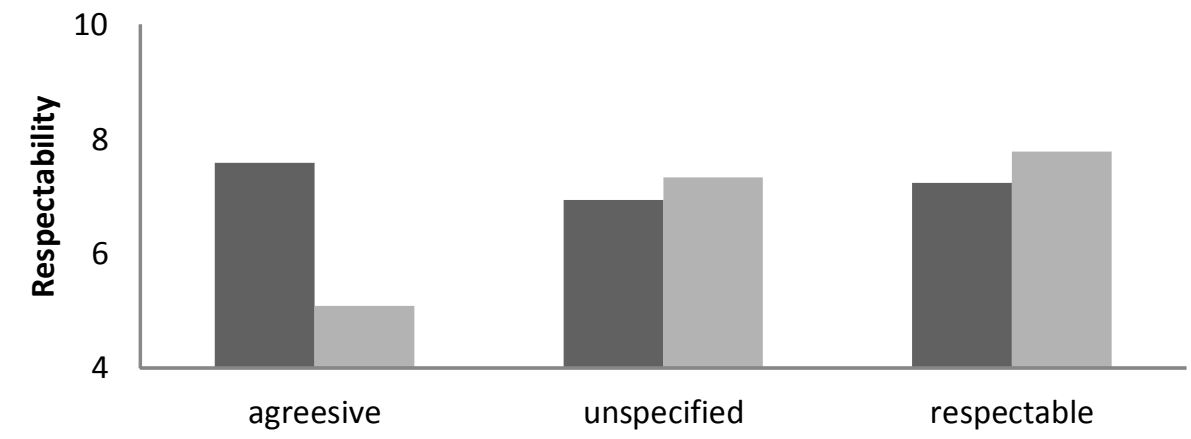

Figure 8. Perceived respectability of female actors as seen by women divided by context and clothing color 


\section{DISCUSSION}

In the present study, the effect of clothing color and context on perceived aggressivenes was examined. Both clothing color and context influence perceived aggressiveness independently from each other. Both the evalutor's and evaluated's gender play a role in the assessement of aggressiveness. Whereas men wearing black are perceived as more aggressive by both men and women, clothing color does not have any influence on the perceived aggressiveness of women. Those results are in accordance with the results of Frank and Gilovich (1988) and Johnson (2005), who used men as actors (policemen and football players). However, those results provide novel findings in comparison with the research of Vrij (1997), who also found a relationship between clothing color and perceived aggressiveness when using female subjects. Vrij used a very similar design in which the aggressiveness of female suspects presented in photographs was judged and the participants were university students. The main difference between our and Vrij's research study is that Vrij did not control for the participants' gender. Moreover, the studies were conducted in different countries with different cultures (the Czech Republic versus USA). The question is why a woman in black should not be perceived as being more aggressive than a woman in lighter colored clothes. A factor that could play a role in this particular case is that aggressiveness is considered to be a masculine agentic trait (Archer, 2009; Eagly, Steffen, 1984). If due to gender stereotypes a man would be judged as potentially aggressive, his perceived aggressiveness would attain greater variability in compari- son with a woman who would be, due to gender stereotyping, constantly seen as lacking aggressiveness or having very little aggression. The low variability in perceived female aggressiveness will not enable finding differences in situations featuring various clothing color. The influence of gender stereotype diminished when a woman was presented in masculine social role (Bosak, Sczesny, Eagly, 2008). In our case, this could be manifested when manipulating different situational contexts. When a woman was presented as a suspect of a violent offence, variablity in values of her perceived aggressiveness was great and thus a difference in comparison to other situational contexts could have been observed.

Our study has several new findings: first, the observed effect of context on perceived aggressiveness, and also no observed influence of interaction of clothing color and context on perceived aggressiveness. Men wearing black were seen as more aggressive when compared to men wearing lighter colors when presented both as a suspect but also as a candidate for state prosecutor. The effect of clothing color on perceived aggressiveness in various contexts is thus comparable. If a man does not want to induce an impression of aggressiveness, he should not choose black clothes even in situations which do not have any aggressive conotation. In our experiment, no effect of situational context on one's perceived respectability was observed. Similarly, no effect of clothing color on one's perceived respectability was found, which can be explained by the fact that both black and grey color are traditionally colors of conventional, non-eccentric clothing.

If we included more traditional or eccentric colors (e.g., pink, flashy green) in our research, the difference in comparison with 
black would have been observed. This difference would however, not be induced due to the increased perceived respectability of the person wearing black, but due to the decrease in perceived respectability as a result of a person wearing an eccentric color (see explanation for using grey color in the Method section). Impressions of respectability, based on our findings, are induced not via clothing color, but via the appropriate context in which a person is introduced.

According to our results, forming a first impression is influenced by clothing color especially in regards to men. In social situations, in which black clothing is seen as nor$\mathrm{mal} /$ typical, and it is not connected to fighting or competition, a man wearing black will be seen as more aggressive. As a result of this greater perceived aggressiveness, he can create negative emotions in others leading to his decreased popularity (Cairns et al., 1988). Effects observed in suspects of violent offences (jurors might be misled by the clothing color of the suspect), policemen (it is better to use not-black uniforms, which seem aggressive) and sportmen (wear black clothing to intimidate opponents) may also be induced in theatre visitors, sales representatives, or job applicants. Thus, if a man does not want to make an aggressive impression, he may want to dress in lighter colors. He would not be perceived as more respectable in black clothing anyways.

For greater generalization of the results, the biggest limitations of our research study was the usage of only one type of clothing the color of which was manipulated, using young people as actors in the photographs and also the group sample consisting of only high school students. One might think that a different effect of color on perceived aggressiveness or respectability could be demon- strated if various types of clothing were used. For example, a tuxedo is tradionally perceived as celebratory clothing and one wears it for important social occassions. Would a man wearing a black tuxedo be seen as more aggressive, since the tuxedo color is tradionally black?

Similarly to gender, age can play a role in influencing one's perceived aggressiveness and respectability. Whereas gender was transformed to an independent variable in our research, the age of the actors and participants was kept constant. In order to increase external validity, a replication of our study with different group samples (from different cultural backgrounds, or of different age) would be necessary, as well as using different stimuli (various styles of clothing, different ages of the actors).

Besides gender, other personal characteristics of an assessor can influence the process of perceiving aggressiveness and respectability. Social perception is influenced by personality correlates (Block, Funder, 1986), therefore personal characteristics can be considered as mediating or moderating variables in future research.

Received August 29, 2012

\section{REFERENCES}

ADAMS, F.M., OSGOOD, C.E., 1973, A crosscultural study of the affective meanings of colour. Journal of Cross-Cultural Psychology, 4, 135-156. ARCHER, J., 2009, Does sexual selection explain human sex differences in aggression? Behavior and Brain Sciences, 32, 3/4, 1-63.

BLOCK, J., FUNDER, D.C., 1986, Social roles and social perception: Individual differences in attribution and error. Journal of Personality and Social Psychology, 51, 6, 1200-1207.

BOSAK, J., SCZESNY, S., EAGLY, A.H., 2008, Communion and agency judgments of women and men as a function of role information and response 
format. European Journal of Social Psychology, 38, 7, 1148-1155.

CAIRNS, R.B., CAIRNS, B.D., NECKERMAN, H.J., GEST, S.D., GARIÉPY, J.-L., 1988, Social networks and aggressive behavior: Peer support or peer rejection? Developmental Psychology, 24, 6, 815-823.

DAMHORST, M.L., REED, J.A.P., 1986, Clothing color value and facial expression: Effects on evaluations of female job applicants. Social Behavior and Personality: An International Journal, 14, 1, 89-98.

EAGLY, A.H., STEFFEN, V.J., 1984, Gender stereotypes stem from the distribution of women and men into social roles. Journal of Personality and Social Psychology, 46, 4, 735-754.

FRANK, M.G., GILOVICH, T., 1988, The dark side of self- and social perception: Black uniforms and aggression in professional sports. Journal of Personality and Social Psychology, 54, 1, 74-85.

JOHNSON, R.R., 2005, Police uniform color and citizen impression formation. Journal of Police \& Criminal Psychology, 20, 2, 58-66.

KAYA, N., EPPS, H.H., 2004, Relationship between color and emation: A study of college student. College Student Journal, 38, 3, 396-405.

MAIER, M., BARCHFELD, P., ELLIOT, A., PEKRUN, R., 2009, Context specificity of implicit preferences: The case of human preference for red. Emotion, 9, 5, 734-738.

NICKELS, E., 2008, Good guys wear black: Uniform color and citizen impressions of police. Policing: An International Journal of Police Strategies \& Management, 31, 1, 77-92.

RADELOFF, D., 1990, Role of color in perception of attractiveness. Perceptual and Motor Skills, $71,1,151-160$.

SHERMAN, G.D., CLORE, G.L., 2009, The color of sin, white and black are perceptual symbols of moral purity and pollution. Psychological Science, 20,8,1019-1025.

TURNER, B.F., 1992, Gender differences in old age in ratings of aggression/assertiveness. Current Psychology, 11, 2, 122-127.

VRIJ, A., 1997, Wearing black clothing: The impact of offenders' and suspects' clothing on impression formation. Applied Cognitive Psychology, $11,47-53$.

VRIJ, A., PANNELL, H., OST, J., 2005, The influence of social pressure and black clothing on crime judgements. Psychology, Crime \& Law, 11, 3, 265-274.

WITTENBRINK, B., JUDD, C., PARK, B., 2001, Spontaneous prejudice in context: Variability in automatically activated attitudes. Journal of Personality and Social Psychology, 81, 5, 815827 .

\title{
ČERNÁ BARVA A SITUAČNÍ KONTEXT: FAKTORY OVLIVŇUJÍCÍ VNÍMÁNÍ AGRESIVITY A SERIÓZNOSTI JEDNOTLIVCE
}

\author{
P. Li n h a r tová, A. T a p a l, L. B r a b e n e c, R. M a c e c e k, J. J. B u c h t a,
} J. P r o c há z k a, S. J e ž e k, M. V a c u lí k

Souhrn: Článek se zaměřuje na vliv barvy oblečení a situačního kontextu na utváření dojmu o člověku. Zjišt'ujeme, zda jsou lidé hodnocení jako více agresivní (1) Pokud na sobě mají černé oblečení, (2) V agresivním situačním kontextu. Dále zkoumáme, zda jsou lidé hodnocení jako serióznější (1) Pokud na sobě mají černé oblečení, (2) V seriózním situačním kontextu. Vzorek experimentu tvoří 475 studentů středních škol, kteří posuzovali osoby na počítačově upravených fotografiích v náhodně vylosovaných barvách oblečení a situačních kontextech. Podle výsledků jsou muži na rozdíl od žen hodnoceni jako agresivnější pokud na sobě mají oblečení černé barvy. $\mathrm{Na}$ hodnocení serióznosti nemá barva oblečení vliv. Muži i ženy jsou hodnoceni jako agresivnější v agresivním situačním kontextu a jako serióznější v seriózním situačním kontextu a to bez ohledu na barvu jejich oblečení. 